\title{
Warming mineralises young and old soil carbon equally
}

\author{
F. Conen ${ }^{1}$, J. Leifeld ${ }^{2}$, B. Seth ${ }^{1}$, and C. Alewell ${ }^{1}$ \\ ${ }^{1}$ Institute of Environmental Geosciences, University of Basel, Bernoullistrasse 30, 4056 Basel, Switzerland \\ ${ }^{2}$ Agroscope Reckenholz-Tänikon Research Station ART, Reckenholzstrasse 191, 8046 Zürich, Switzerland
}

Received: 3 August 2006 - Published in Biogeosciences Discuss.: 29 August 2006

Revised: 25 October 2006 - Accepted: 7 November 2006 - Published: 7 November 2006

\begin{abstract}
The temperature sensitivity of soil organic carbon decomposition is critical for predicting future climate change because soils store 2-3 times the amount of atmospheric carbon. Of particular controversy is the question, whether temperature sensitivity differs between young or labile and old or more stable carbon pools. Ambiguities in experimental methodology have so far limited corroboration of any particular hypothesis. Here, we show in a clear-cut approach that differences in temperature sensitivity between young and old carbon are negligible. Using the change in stable isotope composition in transitional systems from $\mathrm{C} 3$ to $\mathrm{C} 4$ vegetation, we were able to directly distinguish the temperature sensitivity of carbon differing several decades in age. This method had several advantages over previously followed approaches. It allowed to identify release of much older carbon, avoided un-natural conditions of long-term incubations and did not require arguable curve-fitting. Our results demonstrate that feedbacks of the carbon cycle on climate change are driven equally by young and old soil organic carbon.
\end{abstract}

\section{Introduction}

Climate change is a process happening over decades. It is mainly driven by increasing concentrations of atmospheric $\mathrm{CO}_{2}$ (Houghton, 2005). Predictions of future $\mathrm{CO}_{2}$ concentrations significantly depend on the effect of warming on the release of $\mathrm{CO}_{2}$ from decomposing soil organic matter (Jones et al., 2003, 2005) and on the possible duration of this effect. If only young and more labile soil organic matter are sensitive to warming (Melillo et al., 2002), any feedback between climate change and soil carbon would be minor and short-lived because the greatest fraction of soil organic matter is of greater age and more stable. A larger effect would

Correspondence to: F. Conen

(franz.conen@unibas.ch) be expected, if all soil carbon would have the same temperature sensitivity (Townsend et al., 1997; Diomaeva et al., 2002; Fang et al., 2005, 2006), or if old carbon would react more strongly to warming than young carbon (Bol et al., 2003; Knorr et al., 2005; Fierer et al., 2005; Leifeld and Fuhrer, 2005). The latter, currently most discussed proposition, would imply that global warming leads to an even stronger increase in the mobilisation of carbon pools than suggested by any previous hypothesis. Investigating the temperature sensitivity of different fractions of soil organic matter has proven difficult (Reichstein et al., 2005; Davidson and Janssens, 2006). Three approaches have been followed so far. One has been to expose soils to different temperatures over several months or years while measuring $\mathrm{CO}_{2}$ release (Townsend et al., 1997; Giardina and Ryan, 2000; Melillo et al., 2002; Knorr et al., 2005, Fang et al., 2005). Usually, $\mathrm{CO}_{2}$ effluxes were observed to decrease with time as the fraction of young compounds gets smaller (Townsend et al., 1997; Waldrop et al., 2004). Response to temperature changes towards the end of the observation period were assumed representative for older fractions of soil organic matter. Yet, only a small proportion of the young carbon is lost in the process and most of the $\mathrm{CO}_{2}$ at the end of the observation periods might still originate from the young fraction. Thus, information about older carbon is very limited. Interpretation of results from this type of experiment strongly depend on the applied model. The same set of data can be used to support contrasting hypotheses (Knorr et al., 2005; Reichstein et al., 2005; Fang et al., 2006). The second approach to study temperature sensitivity is to compare soil carbon of different qualities by means of physical-chemical fractionation and to investigate them separately (Leifeld and Fuhrer, 2005) or to incubate soil from different soil horizons (Fierer et al., 2003; Fang et al., 2005) under the premise that they represent different stabilities. Yet, the destructive nature of the first approach hampers the transferability of its results to natural conditions, and an unequivocal assignment of the evolved

Published by Copernicus GmbH on behalf of the European Geosciences Union. 

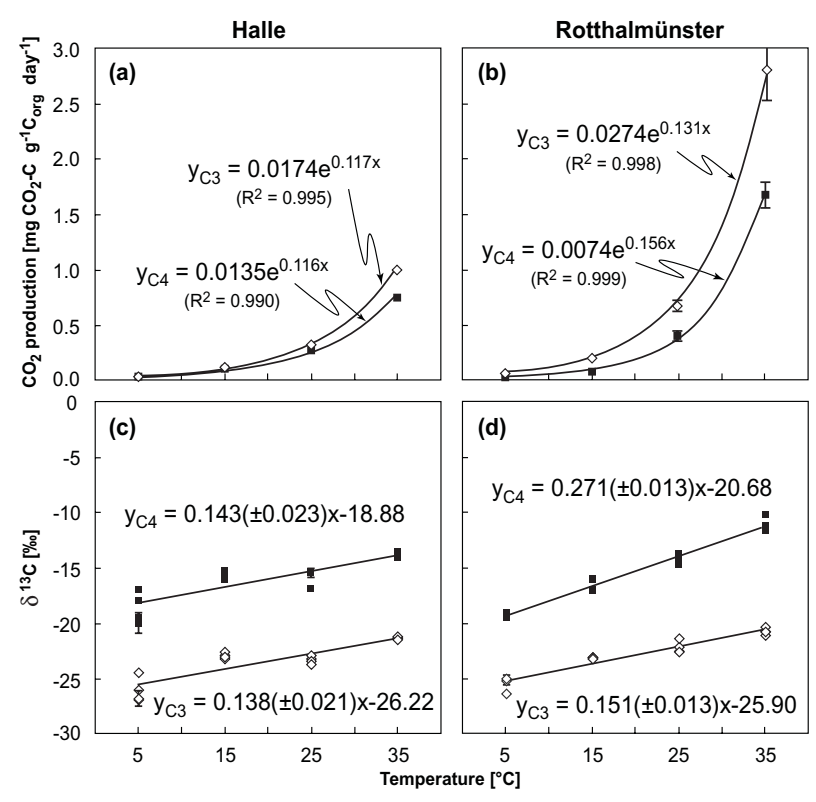

Fig. 1. Mean temperature-dependent respiration rates at (a), Halle; (b), Rotthalmünster under continuous C3 vegetation (open diamonds) and where vegetation had changed to $\mathrm{C} 4$ (closed squares) (error bars indicate \pm 1 s.d.; $\mathrm{n}=4$ ). Effect of temperature on $\delta^{13} \mathrm{C}$ values of $\mathrm{CO}_{2}$ released at (c), Halle; (d), Rotthalmünster for soils under continuous $\mathrm{C} 3$ vegetation (open diamonds) and soils, where vegetation had changed to $\mathrm{C} 4$ (closed squares) (error bars indicate the internal analytical error, where larger than the symbol). Values in brackets in the regression equations in (c) and (d) indicate the error of the slope.

$\mathrm{CO}_{2}$ to young vs. old organic matter is hampered for both. The third approach makes use of different isotopic signatures in $\mathrm{CO}_{2}$ derived from young and old soil carbon, either after a transition from $\mathrm{C} 3$ to $\mathrm{C} 4$ vegetation or after spiking with ${ }^{14} \mathrm{C}$ that ocurred after 1950, and has been applied in long-term incubation studies (Dioumaeva et al., 2002; Bol et al., 2003; Waldrop and Firestone, 2004). Here, we follow the third approach in a short-term incubation study to avoid alteration of the soil through exhaustion of labile carbon or changes in microbial community structure as common in long-term incubation studies.

\section{Material and methods}

Change of vegetation from $\mathrm{C} 3$ to $\mathrm{C} 4$ type allows to distinguish between soil carbon pools originating from the time before and after the changes (Balesdent et al., 1987) as well as their respective contribution to $\mathrm{CO}_{2}$ production (Townsend et al., 1997; Waldrop et al., 2004). The fraction of new carbon equals the difference in $\delta^{13} \mathrm{C}$ between $\mathrm{C} 3$ soil (or $\mathrm{CO}_{2}$ ) and $\mathrm{C} 4$ soil (or $\mathrm{CO}_{2}$ ) divided by the difference in $\delta^{13} \mathrm{C}$ between previous $\mathrm{C} 3$ and new $\mathrm{C} 4$ carbon input. To make use of such natural isotope enrichement, we collected soil samples during the winter of 2005/2006 from the ploughlayer $(0-30 \mathrm{~cm})$ of two sets of split cereal fields in Germany where the vegetation on one part had changed from continuous $\mathrm{C} 3$ to a monoculture of $\mathrm{C} 4$ vegetation, while the other part remained as $\mathrm{C} 3$ (Tab. 1). Litter inputs on the $\mathrm{C} 4$ plots were smaller in Halle (HL), where whole plants were harvested, than in Rotthalmünster (RM), where only grain was removed from the field. Fresh samples were sieved $(2 \mathrm{~mm})$, homogenised and incubated at $15^{\circ} \mathrm{C}$ for several days before being split into 32 units of $5.0 \mathrm{~g}$ per site and vegetation type. The $5.0 \mathrm{~g}$ samples were placed into $12 \mathrm{ml}$ Exetainer vials (Labco, High Wycombe, UK), three times evacuated and flushed with $\mathrm{CO}_{2}$-free air, equilibrated to atmospheric pressure and immediately placed in one of four temperature controlled water baths $\left(5,15,25\right.$ and $35^{\circ} \mathrm{C}, 8$ replicates per temperature treatment). The evolution of $\mathrm{CO}_{2}$ concentrations within the vials was monitored on four of the eight replicates through repeated extraction of $1 \mathrm{ml}$ headspace gas and its immediate analysis on a gas chromatograph with methaniser and flame ionisation detector (model 8610C, SRI Instruments, Torrance, CA, USA). When concentrations of around $1000 \mathrm{ppm} \mathrm{CO}_{2}$ were reached, headspace $\mathrm{CO}_{2}$ in the remaining four replicates of each treatment were measured for carbon isotope ratios using a continuous flow isotope ratio mass spectrometer (CF-IRMS, DELTA ${ }^{\text {plus }} \mathrm{XP}$, Thermo Finnigan, Bremen, Germany) equipped with a GasBench II following standard processing techniques and a backflushing system (Seth et al., 2006). This allowed for the comparison of essentially the same substrate quality independent of temperature. The duration of the incubations ranged from a few hours at $35^{\circ} \mathrm{C}$ to up to 6 days at $5^{\circ} \mathrm{C}$. Isotope ratios are reported as $\delta^{13} \mathrm{C}$ values relative to VPDB [\%o]. Isotope ratios of soil carbon were obtained using an elemental analyzer (Flash-EA 1112, Thermo Electron, Milano, Italy) connected to our CF-IRMS.

\section{Results and discussion}

Isotopic signatures of $\mathrm{C} 4$ vegetation are enriched in ${ }^{13} \mathrm{C}$ relative to C3 vegetation by $16.8 \%$ in Halle (John et al., 2003) (HL) and by $14.1 \%$ in Rotthalmünster (Ludwig et al., 2005) (RM). Isotopic values of $\mathrm{C} 3$ and $\mathrm{C} 4$ litter compared to the $\delta^{13} \mathrm{C}$ of soils allows the calculation of old carbon (e.g. originating from before the change to $\mathrm{C} 4$ ) and young carbon. At $\mathrm{HL}, 13 \%$ of soil carbon were younger than 45 years and contributed $44 \%$ of $\mathrm{CO}_{2}$ between 5 and $35^{\circ} \mathrm{C}$ on average. In RM, $43 \%$ of soil carbon were less than 26 years old and contributed $55 \%$ of the total $\mathrm{CO}_{2}$ emission. The smaller proportion of $\mathrm{C} 4$ soil carbon at HL despite the earlier change to this vegetation type results from smaller litter inputs. At both sites, respiration rates were somewhat smaller at $\mathrm{C} 4$ sites. Values of $\mathrm{Q}_{10}$ were identical (3.2) on both plots at HL (Fig. 1a). At RM, the $\mathrm{Q}_{10}$ value of the soil with $\mathrm{C} 4$ vegetation was greater (4.8) than under contin- 
Table 1. Summary information on sites from where the studied soil samples were taken at a depth of 0-30 cm in winter 2005-2006.

\begin{tabular}{|c|c|c|c|c|}
\hline & \multicolumn{2}{|c|}{ Halle } & \multicolumn{2}{|c|}{ Rotthalmünster } \\
\hline & $\mathrm{C} 3$ continuous & $\mathrm{C} 3$ changed to $\mathrm{C} 4$ & $\mathrm{C} 3$ continuous & $\mathrm{C} 3$ changed to $\mathrm{C} 4$ \\
\hline Vegetation before change & Rye & Rye & Wheat & Wheat \\
\hline Year of change to $C 4$ & & 1961 & & 1979 \\
\hline Vegetation since change & Rye & Maize & Wheat & Maize \\
\hline Annual precipitation & \multicolumn{2}{|c|}{$465 \mathrm{~mm}$} & \multicolumn{2}{|c|}{$886 \mathrm{~mm}$} \\
\hline Mean annual temperature & \multicolumn{2}{|c|}{$9.2^{\circ} \mathrm{C}$} & \multicolumn{2}{|c|}{$8.7^{\circ} \mathrm{C}$} \\
\hline Soil texture (sand, silt, clay) & \multicolumn{2}{|c|}{$69 \%, 23 \%, 8 \%$} & \multicolumn{2}{|c|}{$10 \%, 73 \%, 17 \%$} \\
\hline Soil organic carbon & $1.09 \%$ & $1.12 \%$ & $1.27 \%$ & $1.37 \%$ \\
\hline$\delta^{13} \mathrm{C}$ in soil organic carbon & $-25.7 \%$ & $-23.5 \%$ & $-26.7 \%$ & $-20.6 \%$ \\
\hline
\end{tabular}

uous $\mathrm{C} 3$ vegetation (3.7) (Fig. 1b). Interestingly, the $\delta^{13} \mathrm{C}$ value in $\mathrm{CO}_{2}$ was temperature-dependent under continuous $\mathrm{C} 3$ vegetation. At both sites, increasing temperatures led to increasingly enriched $\delta^{13} \mathrm{C}$ values of about $1.38( \pm 0.21) \%$ and $1.51( \pm 0.13) \%$ per $10^{\circ} \mathrm{C}$ at $\mathrm{HL}$ and RM, respectively. These values were calculated from the slope of regression lines through plots of $\delta^{13} \mathrm{C}$ in $\mathrm{CO}_{2}$ against incubation temperature (Figs. 1c, d). Trends were reproducible when samples first incubated at 5 and $35^{\circ} \mathrm{C}$ were incubated a second time at the opposite end of the temperature range. These trends stress the importance of control treatments in studies based on $\mathrm{C} 3$ to $\mathrm{C} 4$ vegetation change. Since we have not further investigated the cause of the temperature dependence of $\delta^{13} \mathrm{C}$ in our control treatments, we can only speculate about possible mechanisms involved. They could indicate increasing decomposition at higher temperatures of compounds generally enriched in ${ }^{13} \mathrm{C}$ against background, such as sugars, amino-acids, hemicellulose or pectin (Glaser, 2005, and references therein). They could also be caused by a growing importance of fungal respiration relative to microbial respiration at higher temperatures (Kelliher et al., 2005, and references therein). However, it is more likely that they are caused by the Raleigh fractionation in combination with metabolic branching (Schmidt, 2003). At moderate temperatures soil microbial organisms exhibit low metabolic quotients suggesting that only between 70 to $50 \%$ of carbon is respired. In this case, isotope fractionation during the pyruvate-dehydrogenase reaction (Melzer and Schmidt, 1987) liberates depleted carbon for respiration. However, at higher temperatures the metabolic quotient is decreasing and most carbon is used for respiration, so that the pyruvatedehydrogenase reaction is almost complete and no fractionation occurs. Consequently, respired carbon will be isotopically enriched with increasing temperature. A further possibility to explain the temperature dependent fractionation in the $\mathrm{C} 3$ soil could be a decrease in the activity of Gramnegative bacteria relative the activity of Gram-positive bacteria with increasing temperature. Gram-negative bacteria preferentially degrade isotopically more depleted plant car- bon whereas Gram-positive bacteria degrade relatively more enriched soil organic matter. This was recently confirmed for both study sites using compound specific ${ }^{13} \mathrm{C}$ and ${ }^{14} \mathrm{C}$ contents of microbial phospholipid fatty acids (Kramer and Gleixner, 2006). Trends in $\delta^{13} \mathrm{C}$ of respired $\mathrm{CO}_{2}$ with temperature were also found in other studies. Biasi et al. (2005) and Andrews et al. (2000) found increasing temperature to result in increasingly depleted $\delta^{13} \mathrm{C}$ of respired $\mathrm{CO}_{2}$, which is in contrast to our findings and probably the result of changes in microbial community structure as a reaction to a long-term temperature change.

To test differences in temperature sensitivity of young and old carbon, we compared changes in the isotopic signature of $\mathrm{CO}_{2}$ across the studied temperature range between the $\mathrm{C} 3$ soils and the soils where vegetation changed from $\mathrm{C} 3$ to $\mathrm{C} 4$ type. At $\mathrm{HL}$, the mean increase in $\delta^{13} \mathrm{C}$ values of released $\mathrm{CO}_{2}$ was the same for both soils (Fig. 1c). The difference $\left(0.05 \%\right.$ ) per $10^{\circ} \mathrm{C}$ increase in temperature was much smaller than the combined errors of the slopes $( \pm 0.31 \%$ ) . This indicates that at this site, carbon older or younger than 45 years respectively has the same temperature sensitivity. At $\mathrm{RM}, \delta^{13} \mathrm{C}$ values of soil 26 years under $\mathrm{C} 4$ vegetation were slightly more enriched with increasing temperatures (Fig. 1d). A temperature increase of $10^{\circ} \mathrm{C}$ resulted on average in an enrichment $1.20( \pm 0.18) \%$ o larger than in soil under continuous $\mathrm{C} 3$ vegetation. In other words, a conceivable temperature increase of $5^{\circ} \mathrm{C}$ above the current mean annual temperature of $8.7^{\circ} \mathrm{C}$ by the end of this century, would cause a $9.6 \%$ increase in stimulation of the decomposition of soil carbon younger than 26 years, compared with older soil carbon. The statistical significance of this result underlines the precision of our approach. However, unlike at HL, the $\mathrm{Q}_{10}$ values differed considerably at RM between the plots. This might result from differences in substrate availability (Davidson and Janssens, 2006). Almost twice the amount of litter is incorporated annually by $\mathrm{C} 4$ compared to $\mathrm{C} 3$ vegetation at RM (Ludwig et al., 2005) because maize produces larger litter quantities than wheat. Thus, sugars, amino-acids, hemicellulose or pectin enriched in $\delta^{13} \mathrm{C}$ against the rest of 
the younger carbon background as well as the ratio of Gramnegative to Gram-positive bacteria might not be exactly the same under $\mathrm{C} 4$ and $\mathrm{C} 3$ vegetation at the $\mathrm{RM}$ site. Thus, the greater enrichment of $\mathrm{CO}_{2}$ in ${ }^{13} \mathrm{C}$ with increased temperature at the $\mathrm{C} 4$ site might not necessarily indicate a greater temperature sensitivity of younger soil organic carbon. It could equally result from a greater influence of the same factors that have possibly caused the ${ }^{13} \mathrm{C}$ enrichment of $\mathrm{CO}_{2}$ at the $\mathrm{C} 3$ control sites. At HL, grain and straw were removed from both parts of the field (John et al., 2003) and therefore annual carbon inputs to soil and $\mathrm{Q}_{10}$ values were more similar. Taking this into consideration, we conclude that albeit detectable, the small effect observed at RM is likely to be the result of different amounts of annual carbon input rather than being a real difference in temperature sensitivities between young and old carbon.

This result and the robustness of our findings may help to reduce the uncertainty in predicting changes in atmospheric $\mathrm{CO}_{2}$ concentrations associated with the long-term response of soil carbon decomposition to increasing temperatures. Our study was limited to agricultural soils but natural soils may behave similarly. Unlike previous studies based on a shift from $\mathrm{C} 3$ to $\mathrm{C} 4$ vegetation, our results were neither influenced by changes in microbial community composition (Waldrop and Firestone, 2004) nor by different substrate qualities in our temperature treatments (Bol et al., 2003). Our results suggest that the carbon cycle feedback on climate change will neither be small and short lived until young carbon pools have reached a new dynamic equilibrium, nor accelerating with a growing share of $\mathrm{CO}_{2}$ from old carbon, but steady and persistent in agreement with Townsend et al. (1997) and Fang et al. (2005, 2006). Similarly, for northern peatlands, Dioumaeva et al. (2002) found increasing rates of respiration with temperature but an unchanged relative proportion of ${ }^{14} \mathrm{C}$ in respired $\mathrm{CO}_{2}$, which may suggest an equal sensitivity of old and young carbon to warming also for this important source of $\mathrm{CO}_{2}$.

Acknowledgements. We would like to thank J. Sirch and R. Obermeier from the Agricultural College Rotthalmünster and L. Schmidt from the University Halle-Wittenberg for providing soil samples.

Edited by: T. J. Battin

\section{References}

Andrews, J. A., Matamala, R., Westover, K. M., and Schlesinger, W. H.: Temperature effects on the diversity of soil heterotrophs and the delta $\mathrm{C}-13$ of soil-respired $\mathrm{CO}_{2}$, Soil Biol. \& Biochem., 32, 699-706, 2000.

Balesdent, J., Mariotti, A., and Guillet, B.: Natural C-13 abundance as a tracer for studies of soil organic-matter dynamics, Soil Biol. \& Biochem., 19, 25-30, 1987.

Biasi, C., Rusalimova, O., Meyer, H., Kaiser, C., Wanek, W., Barsukov, P., Junger, H., and Richter, A.: Temperature-dependent shift from labile to recalcitrant carbon sources of arctic heterotrophs, Rapid Commun. Mass Spectrom., 19, 1401-1408, 2005.

Bol, R., Bolger, T., Cully, R., and Little, D.: Recalcitrant soil organic materials mineralize more efficiently at higher temperatures, J. Plant Nutr. Soil Sci., 166, 300-307, 2003.

Davidson, E. A. and Janssens, I. A.: Temperature sensitivity of soil carbon decomposition and feedbacks to climate change, Nature, 440, 165-173, 2006.

Dioumaeva, I., Trumbore, S., Schuur, E. A. G., Goulden, M. L., Litvak, M., and Hirsch, A. I.:. Decomposition of peat from upland boreal forest: Temperature dependence and sources of respired carbon, J. Geophys. Res. 108(D3), 8222, doi:10.1029/2001JD000848, 2002.

Fang, C., Smith, P., Moncrieff, J. B., and Smith, J. U.: Similar response of labile and resistant soil organic matter pools to changes in temperature, Nature, 433, 57-59, 2005.

Fang, C., Smith, P., and Smith, J. U.: Is resistant soil organic matter more sensitive to temperature then the labile organic matter?, Biogeosciences, 3, 65-68, 2006,

http://www.biogeosciences.net/3/65/2006/.

Fierer, N., Craine, J. M., McLaughlan, K., and Schimel, J. P.: Litter quality and the temperature sensitivity of decomposition, Ecology, 86, 320-326, 2005.

Fierer, N., Allen, A. S., Schimel, J. P., and Holden, P. A.: Controls on microbial $\mathrm{CO}_{2}$ production: A comparison of surface and subsurface soil horizons, Glob. Change Biol., 9, 1322-1332, 2003.

Giardina, C. P. and Ryan, M. G.: Evidence that decomposition rates of organic matter in mineral soil do not vary with temperature, Nature, 404, 858-861, 2000.

Glaser, B.: Compound-specific stable-isotope $\left(\delta^{13} \mathrm{C}\right)$ analysis in soil science, J. Plant Nutr. Soil Sci., 168, 633-648, 2005.

Houghton, J.: Global warming, Rep. Prog. Phys., 68, 1343-1403, 2005.

John, B., Ludwig, B., and Flessa, H.: Carbon dynamics determined by natural $\mathrm{C}-13$ abundance in microcosm experiments with soils from long-term maize and rye monocultures, Soil Biol. \& Biochem., 35, 1193-1202, 2003.

Jones, C. D., Cox, P., and Huntingford, C.: Uncertainty in climatecarbon-cycle projections associated with the sensitivity of soil respiration to temperature, Tellus B, 55, 642-648, 2003.

Jones, C., McConnell, C., Coleman, K., Cox, P., Falloon, P., Jankinson, D., and Powlson, D.: Global climate change and soil carbon stocks; predictions from two contrasting models for the turnover of organic carbon in soil, Glob. Change Biol., 11, 154-166, 2005.

Kelliher, F. M., Barbour, M. M., and Hunt, J. E.: Sucrose application, soil microbial respiration and evolved carbon dioxide isotope enrichment under contrasting land uses, Plant and Soil, 268, 233-242, 2005.

Knorr, W., Prentice, I. C., House, J. I., and Holland, E. A.: Longterm sensitivity of soil carbon turnover to warming, Nature, 433, 298-301, 2005.

Kramer, C. and Gleixner, G.: Variable use of plant- and soilderived carbon by microorganisms in agricultural soils, Soil Biol. Biochem., 38, 3267-3278, 2006.

Leifeld, J. and Fuhrer, J.: The temperature response of $\mathrm{CO}_{2}$ production from bulk soils and soil fractions is related to soil organic matter quality, Biogeochemistry, 75, 433-453, 2005.

Ludwig, B., Helfrich, M., and Flessa, H.: Modelling the long-term 
stabilization of carbon from maize in a silty soil, Plant and Soil, 278, 315-325, 2005.

Melillo, J. M., Steudler, P. A., Aber, J. D., Newkirk, K., Lux, H., Bowles, F. P., Catricala, C., Magill, A., Ahrens, T., and Morisseau, S.: Soil warming and carbon-cycle feedbacks to the climate system, Science, 298, 2173-2175, 2002.

Melzer, E. and Schmidt, H. L.: Carbon isotope effects on the pyruvate-dehydrogenase reaction and their importance for relative C-13 depletion in lipids, J. Biol. Chem., 262, 8159-8164, 1987.

Reichstein, M., Kätterer, T., Andrén, O., Ciais, P., Schulze, E.-D., Cramer, W., Papale, D., and Valentini, R.: Temperature sensitivity of decomposition in relation to soil organic matter pools: critique and outlook, Biogeosciences, 2, 317-321, 2005, http://www.biogeosciences.net/2/317/2005/.
Schmidt, H. L.: Fundamentals and systematics of the nonstatistical distributions of isotopes in natural compounds, Naturwissenschaften, 90, 537-552, 2003.

Seth, B., Schneider, C., and Storck, F.: Improved reliability of oxygen isotopic analysis of water using the Finnigan GasBench II periphery of a continuous flow isotope ratio mass spectrometer by backflushing of the sampling line, Rapid Commun. Mass Spec. 20, 1049-1051, 2006.

Townsend, A. R., Vitousek, P. M., Desmarais, D. J., and Tharpe, A.: Soil carbon pool structure and temperature sensitivity inferred using $\mathrm{CO}_{2}$ and ${ }^{13} \mathrm{CO}_{2}$ incubation fluxes from five Hawaiian soils, Biogeochemistry, 38, 1-17, 1997.

Waldrop, M. P. and Firestone, M. K.: Altered utilization patterns of young and old soil $\mathrm{C}$ by microorganisms caused by temperature shifts and $\mathrm{N}$ additions, Biogeochemistry, 67, 235-248, 2004. 